\title{
MANAJEMEN MUTU PENDIDIKAN PERPSEKTIF PENDIDIKAN ISLAM
}

\author{
Al-Irsyadiyah \\ mrsalirsyadiyah@gmail,com \\ (Fakultas Agama Islam, Universitas Muhammadiyah Tangerang)
}

\begin{abstract}
Abstrak
Manajemen dapat diartikan sebagai pengelolaan, ketatalaksanaan dan penggunaan sumber daya secara efektif untuk mencapai sasaran yang diinginkan. Beberapa hal yang harus dicermati dalam manajemen mutu pendidikan Islam: Perbaikan Terus Menerus, Menetapkan Standar Mutu, Organisasi yang berubah. Peningkatan mutu dilakukan secara menyeluruh. berdasarkan ukuran, kadar, ketentuan dan penilaian tentang kualitas sesuatu barang maupun jasa (produk) sesuai dengan kepuasan pelanggan. Pemanfaatan dilakukan melalui kerjasama secara efektif, efisien, dan produktif untuk mencapai kebahagiaan dan kesejahteraan baik di dunia maupun di akhirat.
\end{abstract}

\section{Kata Kunci: Manajemen, Mutu, Pendidikan Islam.}

\section{A. Pendahuluan}

Pendidikan merupakan "jantung" sekaligus "tulang punggung" masa depan bangsa dan negara. ${ }^{1}$ bahkan keberhasilan suatu bangsa sangat ditentukan oleh keberhasilan dalam memperbaiki dan memperbarui sektor pendidikan. ${ }^{2}$ Pendidikan dilakukan manusia dalam rangka memperbaiki dan meningkatkan taraf hidupnya, melalui proses pendidikan diharapkan manusia menjadi cerdas atau memiliki kemampuan, yang biasa dikenal dengan istilah skill dalam menjalani kehidupannya. $^{3}$

Problema pendidikan yang dihadapi oleh bangsa Indonesia saat ini, tanpa terkecuali pendidikan Islam di antaranya

\footnotetext{
${ }^{1}$ Zian Farodis, Panduan Manajemen Pendidikan ala Harvard University, Yogyakarta: Diva Press, 2011, h. 7

${ }^{2}$ Aulia Reza Bastian, Reformasi Pendidikan: Langkah-langkah Pembaharuan dan Pemberdayaan Pendidikan Dalam Rangka Desentralisasi Sistem Pendidikan Indonesia, Yogyakarta: Lapera Pustaka Utama, 2002, h. 24

${ }^{3}$ Jerry H. Makawimbang, Supervisi dan Peningkatan Mutu Pendidikan, Bandung: CV Alfabeta, 2011, h. 1
}

adalah: 1) masih rendahnya pemerataan memperoleh pendidikan, 2) masih rendahnya mutu dan relevansi pendidikan; 3) masih lemahnya manajemen pendidikan, di samping belum terwujudnya keunggulan ilmu pengetahuan dan teknologi di kalangan akademisi dan kemandirian. Mutu pendidikan Islam belum menunjukan peningkatan yang berarti. Secara fungsional, pendidikan Islam pada dasarnya ditujukan untuk memelihara dan mengembangkan manusia seutuhnya (insan kamil) yakni manusia berkualitas sesuai dengan pandangan Islam. ${ }^{4}$ Mengkaji dan mengembangkan pendidikan Islam untuk melahirkan manusia-manusia unggul (insan kamil) dengan berpegang teguh kepada al-Qur'an dan Sunnah. ${ }^{5}$

\footnotetext{
${ }^{4}$ Achmadi, Ideologi Pendidikan Islam; Paradigma Humanisme Teosentris, Yogyakarta: Pustaka Pelajar, 2010, cet. II, h. 32

${ }^{5}$ Abd. Rachman Assegaf, Filsafat Pendidikan Islam; Paradigma Baru Pendidikan Hadhari Berbasis Integratif-Interkonektif, Jakarta: PT. RajaGrafindo Persada, 2011, h. 2. Lihat juga dalam Abuddin Nata, Ilmu Pendidikan Islam, Jakarta: Kencana, 2010, hlm. 36. Juga dalam Tobrani, Pendidikan Islam; Paradigma Teologis,
} 
Dalam islam untuk melakukan pekerjaan harus terencana, terukur dan terarah, (QS. As-Sajdah [32]:5) sebagai pengejewantahan nilai-nilai Islam hal tersebut mengindikasikan bahwa sesuatu yang akan dikerjakan haruslah terprogram. Pendidikan merupakan struktur pokok yang memberikan fasilitas bagi warga masyarakat untuk bisa menentukan barang dan jasa apa yang diperlukan. ${ }^{6}$ Sedangkan di sisi yang lain, sistem pendidikan Islam merupakan suatu kawah candradimuka pembentuk manusia sempurna sebagai fondasi awal dalam pembangunan peradaban madani, ${ }^{7}$ dan mewujudkan rahmat bagi seluruh umat manusia. ${ }^{8}$

\section{B. Manajemen Mutu Pendidikan Perspektif Pendidikan Islam}

Imam Al-Ghazali, sebagaimana yang dikutip oleh Shihab, menerangkan bahwa seluruh cabang ilmu pengetahuan yang terdahulu dan yang kemudian, yang telah diketahui maupun yang belum, semua bersumber dari Al-Qur'an. ${ }^{9}$ Al-Qur'an

Filosofis dan Spiritualis, Malang: UMM Press, 2008, h. 19. Salah satu contoh ayat tentang manajemen adalah bentuk kata derivasi dari dabbara (mengatur) yang banyak terdapat dalam alQur'an yang pengertian sama dengan hakikat manajemen adalah al-tadbir (pengaturan), yaitu dalam surat as-Sajdah ayat 5 yang mendeskripsikan tentang:

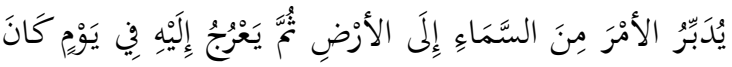

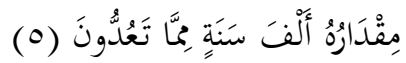

Dia mengatur urusan dari langit ke bumi, kemudian (urusan) itu naik kepada-Nya dalam satu hari yang kadarnya adalah seribu tahun menurut perhitunganmu" (QS. As-Sajdah [32]: 5)

${ }^{6}$ Zamroni, Dinamika Peningkatan Mutu, Yogyakarta: Gavin Kalam Utama, 2011, h. 83

${ }^{7}$ Sukarno, Budaya Politik Pesantren Perspektif Interaksionisme Simbolik, Yogyakarta: Interpena, 2012, h. 15

${ }^{8}$ Abuddin Nata, Ilmu Pendidikan Islam, Jakarta: Kencana Prenada Media Group, 2010, h. 44

${ }^{9}$ M. Quraish Shihab. Wawasan Al-Qur'an; merupakan sumber ilmu pengetahuan yang telah ada, dari Al-Qur'an pula dapat digali dan dikembangkan ilmu-ilmu pengetahuan baru yang belum diketahui oleh manusia sebelumnya.

Manajemen, dapat diartikan sebagai pengelolaan, ketatalaksanaan dan penggunaan sumber daya secara efektif untuk mencapai sasaran yang diinginkan. ${ }^{10}$ Kata manajemen secara maknawi berarti memimpin, membimbing atau mengatur. Sehingga dari asal kata ini manajemen dapat diartikan sebagai pengurusan, pengendalian, memimpin atau membimbing. ${ }^{11}$ Menurut para ahli manajemen adalah proses mendayagunakan orang atau sumber lainnya untuk mencapai tujuan organisasi secara afektif dan efesien. ${ }^{12}$ Batasan manajemen sebagai suatu proses yang berkenaan dengan keseluruhan usaha individu yang dengan bantuan individu lainnya serta sumbersumber lain, dengan menggunakan metode yang efesien dan efektif dalam mencapai tujuan yang ditentukan. ${ }^{13}$

Kata mutu adalah kualitas, yang dalam manajemen, dapat berarti derajat atau tingkat. Secara etimologi kualitas memiliki pengertian yang beragam, dan multi tafsir. Hal ini disebabkan belum ada kesepakatan dan ukuran yang baku tentang arti kualitas, berbeda dengan kuantitas yang dapat dinyatakan secara objektif dan mutlak. Meskipun demikian secara sederhana Vincent dan Jims, mengartikan

Tafsir Maudlu'i atas Pelbagai Persoalan Umat, Bandung: Mizan, 1996. h. 37.

${ }^{10}$ Plus Partanto dan Dahlan Albari. Kamus Ilmiah Popular, Surabaya: Arloka, 2010. h. 440.

${ }^{11}$ Mulyono. Manajemen Administrasi dan Organisasi Pendidikan, Yogyakarta: Ar Ruzz Media, 2008. h. 33.

${ }^{12}$ Muhammad Elyasin dan Nanik Nurhati. Manajemen Pendidikan Islam Yogyakarta Adiya Media Publishing, 2012. h. 60.

${ }^{13}$ Oemar Hamalik. Manajemen Pengembangan Kurikulum Bandung: Remaja Rosda Karya, 2010. h.12. 
kualitas sebagai penggambaran karakteristik langsung dari suatu produk atau hasil suatu aktivitas, seperti performansi, keandalan, kemudahan dalam penggunaan, dan sebagainya. ${ }^{14}$

Kualitas didefinisikan sebagai segala sesuatu yang mampu memenuhi keinginan atau kebutuhan pengguna (meeting the needs of users $).{ }^{15}$ Kualitas terukur melalui tingkat kepuasan pengguna, karena kualitas berkaitan dengan karakteristik produk dan pelayanan yang menyertainya. ${ }^{16}$ Kualitas menurut Pierre dan Simar, adalah pencapaian tujuan yang telah ditetapkan sebelumnya, atau kesesuaian dengan standar yang telah ditentukan. ${ }^{17}$ Sedangkan Bourke, menyatakan kualitas sebagai gambaran dari suatu produk atau hasil kerja. $^{18}$

Kualitas meliputi berbagai aspek berkenaan dengan kriteria atau karakteristik hasil kerja atau kegiatan. Jika dikaitkan dengan manajemen, maka kulitas manajemen atau mutu manajemen berkenaan dengan kriteria yang harus termuat dalam manajemen tersebut. Hal ini karena pada kenyataannya orang yang sama mungkin akan menerapkan konsep yang berbeda pada saat yang lain. Selanjutnya dinyatakan bahwa, secara teoritis, ada dua pendekatan yang digunakan untuk memahami arti kualitas yakni (1) pendekatan deskriptif dan (2)

${ }^{14}$ Vincent A. Zeithami dan Jims M. Bitner. Service Marketing, New York: McGraw-Hill, 2011 h. 14. h. 11

${ }^{15}$ Ellis G. Anon., Quality of Service, 2011.

${ }^{16}$ Sallis, E. Jones. Knowledge Management in Education, (London: Kogan Page Limited), 2012.h. 41.

${ }^{17}$ Pierre M. Campanella dan C. N. Simar., Definition of Quality of Service, New York: SeQuin the National Research \& Education Network, 2001, h. 112.

${ }^{18}$ Bourke D. Piper. Quality Management in Universities Canberra: Australian Government Publishing Service, 2003, h. 8. pendekatan metafisik. ${ }^{19}$

Pendekatan deskriptif, bahwa kualitas adalah gambaran dan karakteristik hasil suatu pekerjaan. Dalam pendekatan ini, sesuatu yang berkualitas dipandang sebagai sesuatu yang bernilai secara subjektif. ${ }^{20}$ Pada pendekatan kedua yang disebut pendekatan metafisik, kualitas dipandang sebagai sesuatu yang tidak hanya dapat dianalisis secara deskriptif tapi juga memiliki kriteria-kriteria, sehingga dapat diukur secara kuantitatif.

Dalam konteks pendidikan pengertian mutu, mengacu pada proses dan hasil pendidikan. Dalam "proses pendidikan" mutu melibatkan berbagai input, seperti; hasil dan bahan ajar, dapat kognitif, afektif, maupun psikomotorik, metodologi pembelajaran yang sangat bervariasi sesuai dengan materi ajar dan kemampuan guru, sarana sekolah/ madrasah, dukungan administrasi dan sarana prasarana dan sumber daya lainnya serta penciptaan suasana yang kondusif.

Mutu dalam konteks "hasil pendidikan" mengacu pada prestasi yang dicapai oleh sekolah/madrasah pada setiap kurun waktu tertentu, biasa tiap akhir satuan pembelajaran, tiap semester, setiap akhir tahun, bahkan 10 tahun. Prestasi yang dicapai atau hasil pendidikan diperoleh menggunakan test kemampuan akademis, melalui ulangan umum, serta prestasi di bidang lainnya seperti; prestasi siswa dalam cabang olah raga, seni atau keterampilan tambahan tertentu misalnya: komputer, beragam jenis teknik, jasa, termasuk prestasi sekolah/madrasah yang tidak dapat dipegang (intangible) seperti;

\footnotetext{
${ }^{19}$ Ara Hidayat dan Imam Machali, pengelolaan pendidikan Konsep, Prinsip dan Aplikasi Dlama Pengelolaan sekolah Madrasah. Yogyakarta: Kaukaba, 2012. h. 109

${ }^{20}$ Ara Hidayat dan Iman Machlai, Pengelolaan pendidikan konsep, prinsip dan aplikasi dalam pengeloaan sekolah Madrasah Yogyakarta: Kaukaba, 2012. h. 15.
} 
disiplin siswa, keakraban antar siswa, saling menghormati, kebersihan, dan lain sebagainya. Mutu antar proses dan hasil pendidikan ternyata memiliki saling keterkaitan.

Agar proses pendidikan tidak salah arah, maka terlebih dahulu mutu hasil pendidikan (ouput dan outcome) dirumuskan oleh sekolah/madrasah, dan harus jelas target yang akan dicapai untuk setiap tahun atau kurun waktu lainnya. Berbagai input dan proses harus selalu mengacu pada mutu-hasil (output) yang ingin dicapai.

Dari pengertian di atas mutu mempunyai makna ukuran, kadar, ketentuan dan penelitian tentang kualitas sesuatu barang maupun jasa yang mempunyai sifat absolut dan relatif. Dalam pengertian yang absolut, mutu merupakan standar yang tinggi dan tidak dapat diungguli. Biasanya disebut dengan istilah baik, unggul, bagus, mahal, mewah dan sebaginya. Jika dikaitkan dengan konteks pendidikan maka konsep pendidikan adalah elit, karena hanya sedikit institusi yang dapat memberikan pengalaman pendidikan dengan mutu tinggi kepada anak didik. Dalam pengertian relative, mutu memiliki dua arti, pertama menyesuaikan diri dengan spesifik, dan kedua berarti memenuhi kebutuhan pelanggan. $^{21}$

Manajemen mutu dalam pendidikan Islam lebih popular dengan sebutan istilah Total Quality Management (mutu terpadu), yang dapat didefinisikan dari tiga kata yaitu: total (keseluruhan), quality (kualitas, derajat/tingkat keunggulan barang atau jasa), management (tindakan, seni, pengendalian, pengarahan). Dengan demikian mutu terpadu, dapat didefinisikan sebagai, sistem manajemen yang berorientasi pada kepuasan pelanggan

\footnotetext{
${ }^{21}$ Umedi.Manajemen Mutu Berbasis Sekolah/ madrasah MMBS. Jakarta: Pusat Kajian Mutu Pendidikan) 2004. h. 211.
}

(customer satisfaction) dengan kegiatan yang diupayakan benar sekali, melalui perbaikan berkesinambungan serta memotivasi karyawan. ${ }^{22}$

Manajemen kualitas terpadu hanya dapat dicapai dengan memperhatikan karakteristik sebagai berikut:

1. Fokus pada pelanggan (internal \& Eksternal),

2. Memiliki obsesi tinggi terhadap kualitas,

3. Menggunakan pendekatan ilmiah dalam pengambilan keputusan dan pemecahan masalah,

4. Memiliki komitmen jangka panjang,

5. Membutuhkan kerjasama tim (teamwork),

6. Memperbaiki proses secara kontinu,

7. Menyelenggarakan pendidikan dan pelatihan,

8. Memberikan kebebasan yang terkendali,

9. Memiliki kesatuan tujuan,

10. Adanya keterlibatan dan pemberdayaan karyawan.

Bill Crash, yang dikutip Fandi dan Diana Anastasia, menyatakan bahwa program mutu terpadu dapat sukses dalam penerapannya, dengan memperhatikan empat hal berikut ini;

1. didasarkan pada kesadaran akan kualitas dan berorientasi pada kualitas dalam semua kegiatannya sepanjang program, termasuk dalam setiap proses dan produk,

2. mempunyai sifat kemanusiaan yang kuat dalam memberlakukan karyawan, mengikutsertakannya, dan memberinya inspirasi,

3. pendekatan desentralisasi yang memberikan wewenang disemua tingkat, terutama di garis depan, sehingga antusiasme keterlibatan dan tujuan bersama menjadi kenyataan, dan

${ }^{22}$ Fandy Tjiptono dan Anastasia Diana. Total Quality Management, Yogyakarta: Penerbit Andi 2001, 2008.h. 112. 
4. diterapkan secara menyeluruh sehingga semua prinsip, kebijaksanaan, dan kebiasaan mencapai setiap sudut dan celah organisasi. ${ }^{23}$

Manajemen pendidikan mutu berlandaskan kepada kepuasan pelanggan sebagai sasaran utama. Pelanggan ada dua aspek yaitu pelanggan internal dan pelanggan eksternal pendidikan dikatakan berkualitas apabila:

1) Pelanggan internal (kepala sekolah, guru, staf tata usaha, pesuruh, penjaga, satpam dan ibu/bpk kantin) berkembang baik fisik maupun psikis. Secara fisik antara lain mendapatkan imbalan finansial. Sedangkan secara psikis adalah bila mereka diberi kesempatan untuk terus belajar mengembangkan kemampuan bakat dan kreativitas.

2) Pelanggan eksternal:

a) Eksternal primer (para siswa) menjadi pembelajar sepanjang hayat, komunikator yang baik, punya keterampilan dalam kehidupan seharihari, integrasi tinggi, pemecah masalah dan pencipta pengetahuan serta menjadi warga negara yang bertanggung jawab.

b) Eksternal sekunder (orang tua pemerintah dan perusahaan): para lulusan dapat memenuhi harapan orang tua, pemerintah dan perusahaan dalam hal menjalankan tugas-tugas yang diberikan kepadanya

c) Eksternal tersier (pasar kerja dan masyarakat luas):para lulusan memiliki kompetensi dalam dunia kerja dan pengembangan masyarakat, sehingga mempe-ngaruhi pada pertumbuhan ekonomi, kesejahteraan rakyat dan keadilan sosial.

${ }^{23}$ Tjiptono, Fandi dan Diana Anastasia. Total Quality Management, Yogjakarta: Andi Offset, 2011. h. 19.
Dalam implementasi manajemen mutu pendidikan Islam ada beberapa hal yang harus dicermati:

1. Perbaikan Terus Menerus. Perbaikan terus menerus harus dilakukan secara menyeluruh yang meliputi semua unsur-unsur yang mempengaruhi manajemen pendidikan Islam, seperti: manajemen proses pembelajaran dan kurikulum pendidikan Islam, manajemen personalia dilembaga pendidikan Islam, perencanaan kebutuhan sumber daya manusia manajemen peserta didik dilembaga pendidikan Islam dan manajemen hubungan lembaga pendidikan Islam dengan masyarakat.

2. Menetapkan Standar Mutu. Rujukan yang dapat digunakan menentukan standar mutu pendidikan adalah Peraturan Pemerintah nomor 2 tahun 2013, yang menyatakan institusi pendidikan harus memperhatikan dan menjaga delapan standar mutu yakni; (a) standar isi, (b) standar proses, (c) standar kompetensi lulusan, (d) standar tenaga kependidikan, (e) standar sarana dan prasarana, (f) standar pengelolaan, (g) standar pembiayaan, dan (i) standar penilaian. Dalam pendidikan Islam mutu yang mengacu kepada output harus menghasilkan minimal dua ranah yaitu; (1) terciptanya manusia yang dapat mengakomodasi seluruh fenomena kehidupannya sesuai dengan ajaran dasar Al-Quran dan as-Sunah, dan (2) terbentuknya manusia yang mempunyai skill kompetitif di bidang ilmu pengetahuan dan teknologi sesuai dengan perkembangan zaman.

3. Organisasi Yang Berubah. Pendidikan akan selalu berubah seiring dengan perubahan zaman, setiap saat pendidikan selalu menjadi fokus perhatian dan bahkan tak jarang menjadi sasaran ketidak puasan banyak pihak karena pendidikan menyangkut 
kepentingan banyak orang, bukan hanya menyangkut investasi dan kondisi kehidupan di masa yang akan datang, melainkan juga menyangkut kondisi dan suasana kehidupan saat ini, bahkan pendidikan menyakut masa depan suatu bangsa. Itulah sebabnya pendidikan senantiasa memerlukan upaya perbaikan dan peningkatan sejalan dengan semakin tingginya kebutuhan dan tuntutan kehidupan masyarakat.

Agar perubahan sesuai dengan yang diinginkan maka empat hal berikut harus dijadikan dasar dalam perubahan suatu sekolah/madrasah yakni:

a) Adaptasi: mampu beradaptasi dengan perubahan dalam lingkungan internal maupun eksternal untuk pembangunan berkelanjutan dan menjadikan sekolah yang efektif.

b) Tujuan perubahan adalah prestasi: apabila sekolah mampu berprestasi dan dapat meningkatkan kemampuan guru dan murid untuk mencapai tujuan.

c) Integritas: integritas dapat menjaga iklim di sekolah menjadi lebih terbuka dan jujur dimana anggota sekolah merasa puas dan bangga.

d) Pola pemeliharaan: pola pemiliharaan dapat mempertahankan loyalitas dan membuat seseorang siswa dan terutama alumni menjadi bangga akan sekolahnya. Ini merupakan tradisi yang baik untuk membuat seseorang ingin menjadi orang yang terbaik.

4. Mempertahankan Hubungan dengan Pelanggan

Pendidikan Islam yang berbasis mutu lebih mengutamakan kepuasan pelanggan, maka perlunya mempertahankan hubungan baik dengan pelanggan menjadi sangat pentang. Inilah yang dikembangkan dalam unit public relations ${ }^{24}$.

Bahwa dalam manajemen berbasis sekolah, guru dan staf tata usaha justru dipandang sebagai pelangggan internal, sedangkan pelajar termasuk orang tua pelajar dan masyarakat umum masuk pada pelanggan eksternal. Jerone S. Arcoro menyampaikan bahwa terdapat lima kerateristik atau indicator suatu sekolah atau lembaga pendidikan yang bermutu yaitu; (a) fokus pada pelanggan, (b) keterlibatan social, (c) pengukuran, (d) komitmen, dan (e) perbaikan berkelanjutan. $^{25}$

Mengkaji dan mengembangkan pendidikan Islam untuk melahirkan manusia unggul dengan berpegang pada Al-Qur'an Hadits Nabi Muhammad SAW. Allah SWT merupakan bentuk kemutlakan pada ranah teoritis, normative maupun aplikatif. Artinya Al-Qur'an dan sunah merupakan sumber utama dan menjiwai pendidikan Islam. Achmadi menyatakan bahwa apapun usaha yang dilakukan untuk mengubah tingkah laku individu baik dalam kehidupan pribadi atau kehidupan kemasyarakatan tidak akan pernah mencapai yang diinginkan, jika sumbernya bukan Al-Qur'an dan Hadits. ${ }^{26}$

Dalam melakukan perubahan harus dilakukan secara bertahap, yakni (1) pencairan, (2) perubahan dan (3) pembekuan ulang.

1) Pencairan (unfreezing), pada tahapan ini, hal-hal yang dilakukan yaitu:

a) Mengidentifikasi, membangun, dan mempublikasikan kebutuhan akan perlunya suatu perubahan,

\footnotetext{
${ }^{24}$ Sudjana. Manajemen Program Pendidikan Bandung: Falah Production, 2004. h.32.

${ }^{25}$ Jerome S. Arcaro. Pendidikan Berbasis Mutu: Perinsip-Perinsip Perumusan Data Tata Langkah PenerapanYogyakarta: Pustaka Pelajar, 2010. h. 36

${ }^{26}$ Achmadi. Ideologi Pendidikan Islam; Paradigma Humanisme Teosentris, Yogyakarta: Pustaka Pelajar, 2010. h. 112
} 
b) Merencanakan tujuan dan kebijakan untuk perubahan melalui mekanisme berbasis sekolah,

c) Menganalisis kekuatan dan mengembangkan strategi perubahan,

d) Menyiapkan kebutuhan psikologi, kognitif, dan afektif serta pihak yang akan terlibat dalam perubahan,

e) Menyiapkan sumber daya untuk perubahan.

2) Perubahan (changing). Pada tahap ini, hal-hal yang harus dilakukan antara lain:

a) Menerapkan perubahan teknologi dalam manajemen dan pengajaran,

b) Menerapkan perubahan budaya berbasis nilai,

c) Mengubah aspek afektif, perilaku, dan kognitif para pelaku yang terlibat baik individu, kelompok, dan sekolah,

d) Memantau proses perubahan dan memastikan kemajuan terhadap tujuan,

e) Menghindari ketidak pastian dan mengurangi penolakan terhadap perubahan,

f) Belajar ide dan teknik baru serta membangun tujuan baru.

3) Pembekuan Ulang (refreezing), tahap ini, hal-hal yang dilakukan yaitu:

a) Mengidentifikasi kebaikan atau keuntungan perubahan,

b) Mengidentifikasi akibat buruk dan menghindarinya,

c) Memperkirakan semua jenis biaya untuk perubahan,

d) Menilai efektivitas perubahan,

e) Membuat rekomendasi untuk yang akan datang,

f) Membuat modifikasi perubahan teknologi,

g) Melembagakan perubahan teknologi yang berhasil, h) Menginternalisasi perubahan budaya yang berhasil,

i) Mengklarifikasi kegagalan dan mendorong pembelajaran yang berkelanjutan. ${ }^{27}$

Pendidikan Islam dalam wacana umum merujuk pada dua pengertian yang merupakan satu kesatuan yaitu:

1) Pendidikan menurut Islam atau pendidikan Islam yakni pendidikan yang dipahami dan dikembangkan dari ajaran dan nilai-nilai fundamental dan yang terkandung dalam sunber dasarnya, yaitu Al-Qur'an dan asSunnah. Dalam pengertian ini pendidikan Islam dapat terwujud pemikiran dan teori pendidikan yang mendasarkan diri atau dikembangkan dari sumber-sumber tersebut.

2) Pendidikan keIslaman atau pendidikan Islam, adalah suatu upaya pendidikan agama Islam atau ajaran Islam dan nilai-nilainya agar menjadi pandangan dan sikap hidup seseorang. Dalam pengertian yang kedua ini pendidikan Islam dapat berwujud, segenap kegiatan yang dilakukan seseorang atau suatu lembaga atau institusi pendidikan tertentu untuk membantu seseorng atau kelompok peserta didik dalam menanamkan dan menumbuhkembangkan ajaran Islam dan nilai-nilainya.

\section{Penutup}

Manajemen pendidikan mutu berlandaskan kepada kepuasan pelanggan sebagai sasaran utama. Pelanggan internal (kepala sekolah, guru, staf tata usaha, pesuruh, penjaga, satpam dan ibu/bpk kantin). Pelanggan eksternal: a). Eksternal

${ }^{27}$ A. Rusdiana, Karakteristik, Strategi, Dan Petunjuk Penerapan Inovasi Pendidikan. Bandung: CV. Pustaka Setia. 2014. h. 92-93 
primer (para siswa) menjadi pembelajar sepanjang hayat, komunikator yang baik, punya keterampilan dalam kehidupan sehari-hari, integrasi tinggi, pemecah masalah dan pencipta pengetahuan serta menjadi warga negara yang bertanggung jawab. b). Eksternal sekunder (orang tua pemerintah dan perusahaan): para lulusan dapat memenuhi harapan orang tua, pemerintah dan perusahaan dalam hal menjalankan tugas-tugas yang diberikan kepadanya. c). Eksternal tersier (pasar kerja dan masyarakat luas): para lulusan memiliki kompetensi dalam dunia kerja dan pengembangan masyarakat, sehingga mempengaruhi pada pertumbuhan ekonomi, kesejahteraan rakyat dan keadilan sosial. Dalam implementasi manajemen mutu pendidikan Islam ada beberapa hal yang harus dicermati: Fokus pada pelanggan (QS. Al Syu'ara [26]: 181183), Kepemimpinan (QS. Al-Ahzab[33]: 21), Keterlibatan semua orang (QS. Al Mulk: 15), Pendekatan proses (QS AlInsyiqaq [84]: 19), Pendekatan proses. (QS. Al-Zumar [39]: 62), Perbaikan terus menerus (QS. Ar-Ra'd : 11), Pendekatan proses pengambilan keputusan (QS. AlSyura: 38), Hubungan dengan pemasok dengan prinsip saling menguntungkan (QS Al-Nisa [4]: 29)

\section{DAFTAR PUSTAKA}

Achmadi, Ideologi Pendidikan Islam; Paradigma Humanisme Teosentris, Yogyakarta: Pustaka Pelajar, 2010, cet. II

Abd. Rachman Assegaf, Filsafat Pendidikan Islam; Paradigma Baru Pendidikan Hadhari Berbasis Integratif-Interkonektif, Jakarta: PT. RajaGrafindo Persada, 2011

Ara Hidayat dan Imam Machali, pengelolaan pendidikan Konsep, Prinsip dan Aplikasi Dlama
Pengelolaan sekolah Madrasah. Yogyakarta: Kaukaba, 2012.

Achmadi. Ideologi Pendidikan Islam; Paradigma Humanisme Teosentris, Yogyakarta: Pustaka Pelajar, 2010.

Abuddin Nata, Ilmu Pendidikan Islam, Jakarta: Kencana Prenada Media Group, 2010

A. Rusdiana, Karakteristik, Strategi, Dan Petunjuk Penerapan Inovasi Pendidikan. Bandung: CV. Pustaka Setia. 2014

Aulia Reza Bastian, Reformasi Pendidikan: Langkah-langkah Pembaharuan dan Pemberdayaan Pendidikan Dalam Rangka Desentralisasi Sistem Pendidikan Indonesia, Yogyakarta: Lapera Pustaka Utama, 2002

Bourke D. Piper. Quality Management in Universities Canberra: Australian Government Publishing Service, 2003

Fandy Tjiptono dan Anastasia Diana. Total Quality Management, Yogyakarta: Penerbit Andi 2001

Jerry H. Makawimbang, Supervisi dan Peningkatan Mutu Pendidikan, Bandung: CV Alfabeta, 2011

Jerome S. Arcaro. Pendidikan Berbasis Mutu: Prinsip-Prinsip Perumusan Data Tata Langkah Penerapan Yogyakarta: Pustaka Pelajar, 2010.

M. Quraish Shihab. Wawasan Al-Qur'an; Tafsir Maudlu'i atas Pelbagai Persoalan Umat, Bandung: Mizan, 1996.

Mulyono. Manajemen Administrasi dan Organisasi Pendidikan, Yogyakarta: Ar Ruzz Media, 2008.

Muhammad Elyasin dan Nanik Nurhati. Manajemen Pendidikan Islam Yogyakarta Adiya Media Publishing, 2012.

Oemar Hamalik. Manajemen Pengembangan Kurikulum Bandung: Remaja Rosda Karya, 2010. 
Plus Partanto dan Dahlan Albari. Kamus Ilmiah Popular, Surabaya: Arloka, 2010.

Pierre M. Campanella dan C. N. Simar., Definition of Quality of Service, New York: SeQuin the National Research \& Education Network, 2001

Sukarno, Budaya Politik Pesantren Perspektif Interaksionisme Simbolik, Yogyakarta: Interpena, 2012

Vincent A. Zeithami dan Jims M. Bitner. Service Marketing, New York: McGraw-Hill, 2011

Sallis, E. Jones. Knowledge Management in Education, (London: Kogan Page Limited), 2012.

Sudjana. Manajemen Program Pendidikan Bandung: Falah Production, 2004.

Umedi. Manajemen Mutu Berbasis Sekolah/madrasah MMBS. Jakarta: Pusat Kajian Mutu Pendidikan) 2004.

Tjiptono, Fandi dan Diana Anastasia. Total Quality Management, Yogjakarta: Andi Offset, 2011.

Zian Farodis, Panduan Manajemen Pendidikan ala Harvard University, Yogyakarta: Diva Press, 2011

Zamroni, Dinamika Peningkatan Mutu, Yogyakarta: Gavin Kalam Utama, 2011 
